\title{
Evaluating the Repellent Properties of Mexican Marigold (Tagetes minuta) Aqueous Extracts on Aphid Population in Rape (Brassica napus)
}

\author{
Nyasha Sakadzo $^{1 *}$, Adonia Chisvuure ${ }^{\mathbf{1}}$ and Rumbidzai Nhara ${ }^{2}$ \\ ${ }^{1}$ Faculty of Agriculture, Zimbabwe Open University, Masvingo Regional Centre, P. $O$. \\ Box 1235, Masvingo, Zimbabwe \\ ${ }^{2}$ Faculty of Natural Sciences, Department of Soil and Plant Sciences, Great Zimbabwe \\ University, P.O. Box 1210, Masvingo, Zimbabwe \\ *Corresponding Author: Nyasha Sakadzo, Faculty of Agriculture, Zimbabwe Open \\ University, Masvingo Regional Centre, P. O. Box 1235, Masvingo, Zimbabwe.
}

Received: February 06, 2020

Published: March 10, 2020

(C) All rights are reserved by Nyasha

Sakadzo., et al.

\begin{abstract}
Aphids (Brevicoryne brassicae) pose a threat to production of most vegetables including rape by sap sucking and transmitting viral diseases. A trial was carried out at the Jichidza High School, Masvingo Zimbabwe (2019) to evaluate the repellent properties of Mexican marigold (Tagetes minuta) aqueous extracts on aphid population in rape (Brassica napus). The experiment was laid out as a randomised complete block design (RCBD) with four treatments $(0 \%, 2 \%, 4 \%$ and $6 \%$ ) concentration of Mexican marigold extracts on rape replicated five times. Application of these concentrations was done at fortnight interval from week one after planting to week six of age. Data on growth rate, aphid counts, and cumulative leaf weight was collected from week three to week six after planting. The results showed that, the effects of Mexican marigold on growth rate, aphid population and cumulative leaf weight were significantly different $(\mathrm{p}<0.05)$. Using 6\% concentration of Mexican marigold aqueous extracts recorded the highest growth rate, lowest aphid population and highest leaf weight as compared to all other treatments. However, results from using 2\% concentration of Mexican marigold aqueous extracts were not significantly different $(p>0.05)$ from the use of $4 \%$ concentration of Mexican marigold aqueous extracts in rape. From the results, it can be concluded that the use of $6 \%$ concentration of Mexican marigold in rape is an effective control method for aphids. From this study, it is recommended that poor smallholder farmers can utilise the repellent properties of Mexican marigold to reduce aphid yield losses in rape.
\end{abstract}

Keywords: Repellent; Brassica napus; Tagetes minuta; Aqueous; Brevicoryne brassicae

\section{Introduction}

Rape (Brassica napus) is a sub-tropical plant which belongs to the family Brassicaceae that include covo (Brassica carinata), mustard (Brassica juncea), cauliflower (Brassica oleracea) and other crucifers [1]. It is a popular vegetable in Zimbabwe rich in vitamins and several other nutrients. Its leaves are rich in vitamin A, ascorbic acid, thiamine and has high levels of glucosinates which during preparation form compounds with anti-oxidants and have anti-cancer activities [2]. Unavailability of inputs and poor crop management has contributed negatively to the yield and quality of the crop [3]. Crop yields have remained far below the crop's genetic potential in small holder sector due to diseases and pest attack. Several pests affect rape including bagrada bugs, diamond black moth, cutworm, white grubs and aphids (Brevicoryne brassica). However, aphids are considered the most common pest of rape by most farmers in Zimbabwe [4].

The aphids feed by sucking the sap from the plant leaves and tender tissues and in large numbers remove sufficient sap to kill the growing tip [5]. Infested seedlings become stunted and their 
form is usually distorted. Excessive feeding on mature plants causes wilting, yellowing and general plant stunting [6]. Aphids have also been identified to transmit more than 23 pathogenic diseases as a vector in many cruciferous plants [7]. Research done by Clayton [8] has shown that aphids are vectors to mosaic diseases causing viruses such as turnip yellow mosaic virus, cauliflower mosaic virus, beet western yellows virus of sugar beets [9] states that aphids threaten profitability of the crop if not properly managed and may induce substantial yield losses of up to 50\%.Many smallholder farmers predominantly use synthetic pesticides which include dimethoate to control aphids [4]. There are however concerns about the risks of chemicals to vegetable producer, consumer and environment. According to Klein-Schwartz., et al. (1997), a total of about 4293 cases of chemical poisoning are recorded each year in United States and about 56 of them lead to fatality.

The study seeks to evaluate the repellent effects of different concentrations of Mexican marigold (Tagetes minuta) aqueous extracts on aphid population in rape (Brassica napus). It is within this challenge that it becomes imperative to explore possible utilization of relatively cheaper, accessible, safer and environmentally friendly alternatives to the presently predominating synthetic pesticides. The use of organic pesticides has been proved very effective as they have anti-feedant and strong pungent repelling action. The use of pest repellent plants is one of the practices that have been re-introduced as a measure to reduce pest population in brassica and proves to be effective in other crops such as cabbage on controlling Diamond Black Moth.

\section{Materials ad Methods}

Study Site

The experiment was carried out at Jichidza High School Horticultural garden located in Zaka district, Masvingo Province, Zimbabwe. The area is found in Agro-ecological Region III located at $30^{\circ} 49^{\prime} \mathrm{E}$ and $20^{\circ} 17^{\prime} \mathrm{S}$ and the altitude is $1030 \mathrm{~m}$ above sea level. The annual temperature ranges from $19-28^{\circ} \mathrm{C}$ and the annual rainfall received ranges from $600-700 \mathrm{~mm}$. Soils at the experimental site are red clays to sandy clay loams derived from Gneissic granite and are generally deep $(0.6-1.0 \mathrm{~m})$.

\section{Experimental design}

The experiment was laid out as a Randomised Complete block design with four treatments replicated three times.

\begin{tabular}{|l|c|}
\hline Treatment & Description \\
\hline T1 & Rape + distilled water (control) (0\%) \\
\hline T2 & Rape+2\% aqueous concentration \\
\hline T3 & Rape+4 \%aqueous concentration \\
\hline T4 & Rape+6 \%aqueous concentration \\
\hline
\end{tabular}

Table 1: Treatment structure.

\section{Preparation of aqueous extracts concentrations}

Extraction of aqueous concentrations of T. minuta was done for all the three experiments. Mexican marigold leaves were harvested at Jichidza High School in the school garden in Masvingo province. Leaves of fully grown plants were washed to remove soil particles. The material was then cut into pieces and shed dried for one month. After drying, the material was crushed into powder form manually using a traditional mortar and pistil. Further grinding was done by using an electric mortar. Four concentrations were made on the basis of weight and volume (extract powder: distilled water); 2 grams of extract powder was added to $100 \mathrm{ml}$ of distilled water to give $2 \%$ concentration of aqueous, 4 grams of extract powder was added to $100 \mathrm{ml}$ of distilled water to give $4 \%$ concentration of aqueous, 6 grams of extract powder was added to $100 \mathrm{ml}$ of distilled water to give $6 \%$ concentration of aqueous. The material (powder and distilled water) was mixed and poured into a conical flask with its mouth closed and kept for 24 hours in the dark at room temperature according to the method used [10]. The four flask were marked with stickers according to the T. minuta concentrations $(0,2,4$ and $6 \%$ ). This was followed by filtration process in two steps, in the first step muslin cloth was used and later the filtrate was allowed to pass through Whatman filter paper no.1. The fourth conical flask was filled with distilled water which acted as the control. The prepared aqueous concentrations were kept in a fridge for convenient use during the experiment [10]. Soap solution was added to each of the four solutions to act as a sticking agent [11].

\section{Experimental procedure}

Land preparation was done one week before planting of rape. 20 plots each measuring $1 \mathrm{~m} \times 1 \mathrm{~m}$ were made and replicates in each block were separated by 1 meter spacing. Well decomposed cattle manure was applied at a rate of 10 tonnes $/ \mathrm{ha}\left(10 \mathrm{~kg} / \mathrm{m}^{2}\right)$ in each plot and incorporated. Randomization using the box method was used to allocate treatments to plots. Six weeks old rape (Brassicca napus) seedlings were sourced from Mitcho Nurseries Masvingo 
and were planted on the $3^{\text {rd }}$ of October 2019. Irrigation was done to field capacity to avoid stressing the seedlings after transplanting. Straight planting rows were made using a garden line and a pre-marked meter rule and dibber were used to mark the planting stations which were spaced uniformly at $20 \mathrm{~cm} \times 25 \mathrm{~cm}$ across all blocks. The four different aqueous concentrations of T. minuta extracts were sprayed in respective plots using a hand operated knapsack sprayer to synchronize aphid infestation on rape with repellent effects of different concentrations. The applications of these concentrations were done at fortnight interval from week one after planting up to week six. No chemicals or inorganic fertilizers were used throughout the experiment. However, basic management practices such as weeding and irrigation were done uniformly.

\section{Data collection}

Growth rate was measured in terms of leaf length. It was recorded from week three up to week six at weekly interval. Three plants were selected from each plot in each treatment and the average length was recorded. From each selected plant in each plot, one leaf from the lower side of the plant was measured throughout the period and was permanently marked to avoid confusion during measurements.

Aphid count (nymphs, winged and wingless adults) was done in the laboratory using a hand lense starting from three weeks to six weeks after planting rape. Three sampled plants for collection of data were selected from the middle row. The sample plants had to be within not less than $1 \mathrm{~m}$ radius from any adjacent group of sample plants to avoid variations that might be a result of contamination from adjacent plots and the two rows guarding each plot were not considered for sampling for the same reason. At three weeks from transplanting rape, aphid count commenced and the operation was done by visual searches. Aphid clusters were removed from the rape plants using a soft brush onto a tray were counting or estimation of the number of aphids was done. An aphid assessment score sheet with scores ranging from 0-5 was used for the mean number of aphids per plant. Fresh weight of marketable leaf bundles were measured using a balance at 6 weeks.

\section{Data analysis}

Data was subjected to ANOVA using Genstat statistical package $14^{\text {th }}$ Edition. Separation of treatment means was done using the Fischer's Least Significance Difference (Lsd) at 5\% significant level.

\section{Results}

Growth rate of rape at 6 weeks

The results showed that there were significant differences $(\mathrm{P}<$ 0.05 ) amongst treatment means at 6 weeks as shown in figure 1 . The highest significant mean growth rate of rape was obtained from Tagetes minuta concentration of $6 \%$ which had a mean growth rate of $15.58 \mathrm{~cm}$ and was significantly different from distilled water and $2 \%$ concentrations. There were no significant differences ( $\mathrm{P}>0.05$ ) between Tagetes minuta concentration of $2 \%$ and $4 \%$ that resulted in mean growth rate of $13.12 \mathrm{~cm}$ and $14.86 \mathrm{~cm}$ respectively. The lowest significant growth rate was obtained from distilled water which recorded a mean growth rate of $12.1 \mathrm{~cm}$.

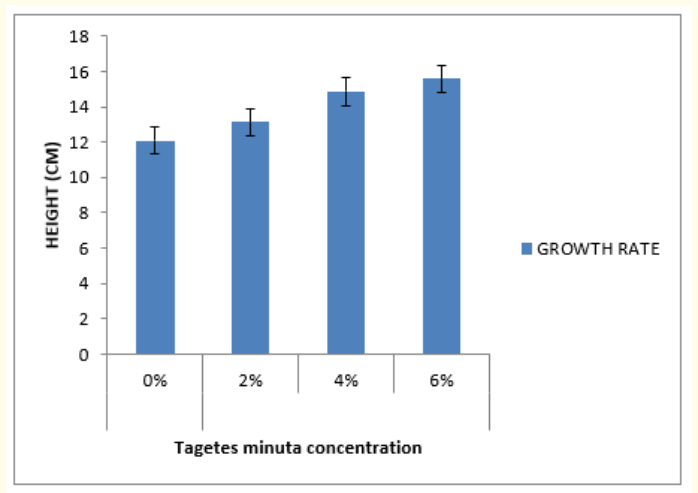

Figure 1: Effects of different aqueous concentrations of Mexican marigold (Tagetes minuta) aqueous extracts on growth rate of rape (Brassica napus) at 6 weeks.

\section{Aphid population on rape at 6 weeks}

The results showed that there was significant difference among treatment means $(\mathrm{P}<0.05)$ at 6 weeks as shown in figure 2 . The highest significant aphid population was shown in distilled water with mean aphid population of (4.2) and was significantly different from all the treatments. There was no significant difference $(\mathrm{P}>$ 0.05 ) between T. minuta concentration of $2 \%$ and $4 \%$ that resulted in mean aphid population of 2.5 and 3 respectively. Tagetes minuta concentration of $4 \%$ and $6 \%$ also showed no significant difference $(\mathrm{P}>0.05)$ recording a mean aphid population of 1.5 and 2.5 respectively. However, there were significant differences between Tagetes minuta concentration of $2 \%$ and $6 \%(\mathrm{P}<0.05)$ showing mean aphid population of 1.5 and 3 respectively. The lowest significant ( $\mathrm{P}$ $<0.05$ ) aphid population was shown on 6\% concentration of Tagetes minuta which scored a mean aphid population of 1.5 . 


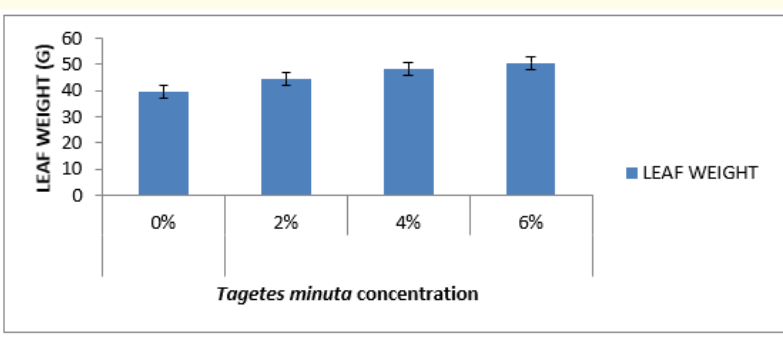

Figure 2: Effects of different aqueous concentration of Mexican marigold (Tagetes minuta) on aphid population on rape (Brassica napus) at 6 weeks.

Fresh weight of rape at 6 weeks

The results showed that there were significant differences ( $P$ $<0.05)$ among treatment means $(\mathrm{P}<0.05)$ at 6 weeks as shown in figure 3. The highest significant mean leaf weight of rape was shown in T. minuta concentration of $6 \%$ with a mean leaf weight of (151.2 g) and was significantly different from distilled water and $2 \%$ with leaf weight of 126.9 and $132.58 \mathrm{~g}$ respectively. There were no significant differences $(\mathrm{P}>0.05)$ between Tagetes minuta concentration of $2 \%$ and $4 \%$ which resulted in mean leaf weight of 132.58 and $141.86 \mathrm{~g}$ respectively. The lowest significant leaf weight was shown in distilled water with mean leaf weight of $126.9 \mathrm{~g}$.

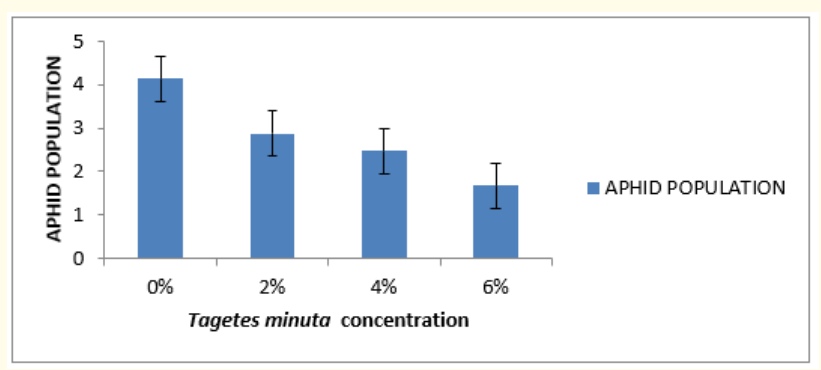

Figure 3: Effects of different aqueous concentrations of Mexican marigold (Tagetes minuta) aqueous extracts on fresh weight of rape (Brassica napus) after harvesting of all the leaves in each treatment 6 weeks.

\section{Discussion}

Effects of different aqueous concentrations of mexican marigold (Tagetes minuta) aqueous extracts on growth rate of rape (Brassica napus)

The highest growth rate of rape was recorded from Tagetes minuta concentration of $6 \%$ whilst distilled water (control) re- corded the least growth rate. This could be attributed to the fact that the rape plants under aqueous concentrations of Mexican marigold benefited indirectly from low aphid population thus increasing their growth rate as most of the apical meristems were not infested with aphids. This is due to the repellence effect of $T$. minuta on various aphids [12]. Rape which was not applied aqueous concentration of Mexican marigold had the lowest growth rate which might have been attributed by the presents of aphids. When aphids are feeding they also concentrate on the apical part of the plant leading to poor growth rate. The aphids feed by sucking the sap from the plant leaves and tender tissues and in large numbers remove sufficient sap to kill the growing tip [5]. Infested seedlings become stunted and their form is usually distorted. Excessive feeding on mature plants causes wilting, yellowing and general plant stunting [6].

Effects of different aqueous concentration of Mexican marigold (Tagetes minuta) on aphid population on rape (Brassica napus)

Results indicated that there were no significant differences among the Tagetes minuta aqueous concentration at three weeks after planting. However, significant differences were noted in week 6. Distilled water had the highest number of aphids because no measure was implemented to guard against aphid infestation on rape. Tagetes minuta concentration of $6 \%$ had least population of aphids. This could have been a result of improved release of repellent characteristics by Mexican marigold extracts [8]. At week 6, rape which was distilled water applied recorded the highest aphid population which increased intensely compared to other concentrations. This could have been attributed to a reduction in food sources as a result of intense competition coupled with the fact that rape applied distilled water harboured a diverse array of pests which included bagrada bugs, lady bird beetles and diamond back moth, which increased pressure and competition on the food source. Continued growth and development of rape plants results in deposition of silica or accumulation of lignin which may have increased fibre content in leaves thus reducing leaf palatability. Aphids are wingless but can produce wings and fly away when food resources are limited or when crowded [9]. This could have led to migration of the aphids to other target areas with abundance of food, such as other adjacent experimental plots with rape. T. minuta concentration of $6 \%$ was the most effective treatment in control of aphids shown by the lowest aphid counts compared to all other treatments. This is highly attributed to the presence of sulphur containing amino acid derivatives in Mexican marigold extracts, which reacts with the enzyme allinase to form allicin and other sulphur compounds. Allicin breakdown into Diallyl disulphide, which is largely responsible for the pungent Mexican marigold odour [13]. 
Effects of different aqueous concentrations of mexican marigold (Tagetes minuta) aqueous extracts on fresh weight of rape (Brassica napus)

The highest yield was obtained from aqueous Tagetes minuta concentration of $6 \%$ whilst distilled water had the least. This might have been attributed to the fact that rape plants which were applied Mexican marigold aqueous concentration benefited indirectly from low aphid population thus increasing yields. Results are in line to findings by Flint [12] who postulated that pungent smell released by Mexican marigold extracts on rape plants repelled aphids. Most of these sap sucking pests caused shrivelling and wilting of leaves as a result of their feeding habits. The low mean fresh weight in this treatment can be explained by the fact that aphids extract photosynthates from plant tissue and excrete toxic compounds which affects the growth of the plant. The greater the number of aphids that feed on the plant, the greater the amount of assimilates that are extracted from the plant. These assimilates are vital raw materials for cell division and cell elongation which determine the eventual yield [14-16].

\section{Conclusions}

The experiment showed that the use of Mexican marigold aqueous extracts is an effective method of repelling aphids with $6 \%$ aqueous concentration being the most effective evidenced by highest growth rate, lowest aphid population and highest fresh leaf weight. The use of Mexican marigold extracts taking advantage of its repellent properties will be eco-friendly, cheaper and effective method of aphid control at concentrations of $2 \%, 4 \%$ and $6 \%$ with $6 \%$ managed to effectively maintain aphid populations below threshold levels of 50 aphids per plant. Results complement works by other researchers like Peet (2007) on cabbage and tomato.

\section{Recommendations}

It can be recommended from the study that farmers should exploit the repellent properties of Mexican marigold aqueous extracts so as to control aphids in rape. There is need to repeat the experiment across a wide range of environments as there might be effects of environment on aphid population.

\section{Bibliography}

1. Baldwin T and Richard L. "Induced Responses to Herbivory". University of Chicago Press (2007).
2. Holland B., et al. "Vegetables, Herbs and Spices". The 5th Supplement to McCance and Wordowson's. The Composition of Foods. 4th Edition. Royal Society of Chemistry.Cambridge.UK (1991).

3. Chadha R., et al. "Monetary policy rules asset prices and exchange rates as affected by agriculture". American Journal of Agricultural Economics 97.2 (2003). 997-1145.

4. Turner A and Chivinge O. Production and marketing of horticultural crops in Zimbabwe: A survey of smallholder farmers in the Mashonaland East province (1999).

5. Pollard DG. "Plant Penetration by Feeding Aphids (Hemiptera. Aphidoidea): A Review". Bulletin of Entomological Research 62 (1973): 631-714.

6. Hill DS. "Brevicoryne brassicae L”. In: Agricultural Insect Pests of the Tropics and their Control. 2nd Edn.Cambridge University Press. London (1993): 154-155.

7. Kessing JLM and Mau RFL. "Crop Knowledge Master Brevicoryne brassicae L”. Cabbage aphid (1991).

8. Clayton E. "A Study of the Mosaic Disease of Crucifers". Journal of Agricultural Research 40.31930 (2012): 263-270.

9. Dube B., et al. Important Vegetable Pest and Diseases in Zimbabwe-Identification and Control (1998).

10. Sakadzo N., et al. "l Herbicidal effects of Datura stramonium (L.) Leaf extracts on Amaranthus hybridus (L.) and Tagetes (L.)". African Journal of Agricultural Research 13.34 (2018): 1754-1760.

11. Nhachi CFB and Kasilo OMJ. "Pesticides in Zimbabwe: Toxicity and Health Implications". University of Zimbabwe, Harare. Zimbabwe (1996).

12. Flint ML. "Pests and Garden and Small Farm: A Growers Guide to Using Less Pesticide". 2nd Edition. Oakland University (1999).

13. Hort Report. "Indian Council of Agricultural Research". New Dehli (2001).

14. Borror DJ., et al. "An Introduction to the Study of Insects". 4th Edition. Holt. Rinehart and Winston. New York (1976): 852.

15. Jackson JE, et al. "Smallholder Horticulture in Zimbabwe". University of Zimbabwe Publications. P.O Box MP 2003. Mt Pleasant. Harare. Zimbabwe (1997). 
16. Rocky Lemus. "Forage Brassicas for Winter Grazing Systems". Mississippi State University. USA (2009).

\section{Assets from publication with us}

- Prompt Acknowledgement after receiving the article

- Thorough Double blinded peer review

- Rapid Publication

- Issue of Publication Certificate

- High visibility of your Published work

Website: www.actascientific.com/

Submit Article: www.actascientific.com/submission.php

Email us: editor@actascientific.com

Contact us: +919182824667 